УДК 633.11.006.83:631.81

(C) 2012

\author{
Жемела Г. П., доктор сільськогосподарських наук, \\ Шакалій С. М., аспірант* \\ Полтавська державна аграрна академія
}

\title{
ВПЛИВ МІНЕРАЛЬНОГО ЖИВЛЕННЯ НА ЕЛЕМЕНТИ ПРОДУКТИВНОСТІ ТА ЯКІСТЬ ЗЕРНА ПШЕНИЦІ ОЗИМОЇ
}

\section{Рецензент - доктор сільськогосподарських наук, професор П. В. Писаренко}

Розглянуто і встановлено закономірності впливу мінерального живлення на формування елементів структури врожайності та якість зерна пшениці озимої. Визначальними факторами для урожайності є управління процесами росту і розвитку, як важливими проявами життєдіяльності організму. Встановлено, щзо найбільш раціональна норма внесення добрив $-N_{85} P_{96} K_{51}+N_{30}$, яка сприяє ефективному підвищенню показників структури врожайності. На формування високопродуктивних посівів також має вплив передпосівна обробка насіння та рівень підживлення Басфоліар 36 Екстра.

Ключові слова: пшениця м'яка озима, мінеральні добрива, елементи структури, урожайність, клейковина, білок.

Постановка проблеми. Проблема одержання якісного екологічно безпечного зерна пшениці м'якої озимої в останні роки набула важливого державного значення. Ї̈ї зерно використовують для виготовлення хлібобулочних, макаронних i кондитерських виробів. Для забезпечення потрібної якості одним із основних резервів $є$ подальше удосконалення технології вирощування пшениці м'якої озимої [3].

У системі агротехнічних заходів особливе значення мають такі фактори, як попередники, дози мінеральних добрив (зокрема азотних) норми висіву насіння, строки збирання стосовно сортових властивостей та погодних умов [3].

Добрива - найефективніший засіб збільшення врожайності сільськогосподарських культур. Застосовуючи добрива, можна керувати процесами живлення рослин, поліпшувати фізичні, фізико-хімічні, агрохімічні та біологічні властивості грунтів, якість зерна [2]. У правильному застосуванні цих факторів - резерв збільшення врожайності та поліпшення якості зерна пшениці м'якої озимої.

Аналіз основних досліджень і публікацій, у яких започатковано розв'язання проблеми. Визначальними факторами для одержання уро- жайності пшениці озимої є управління процесами росту i розвитку як важливими проявами життєдіяльності організму, двома аспектами єдиного процесу життя, взаємопов'язаними i взаємозумовленими [4].

За даними результатів досліджень Г. М. Добриніна, А. М. Данилова, рівень мінерального живлення змінює темпи розвитку вегетативних $\mathrm{i}$ генеративних органів [5].

Добрива є одним із найефективніших і швидкодіючих факторів збільшення врожайності пшениці озимої та поліпшення іiі якості. Збільшення врожайності на 50 \% відбувається за рахунок добрив, на $25 \%$ - сортових властивостей, на 20-25\%поліпшення системи агротехніки [3].

За даними А. М. Павлова і Я. Б. Пругар, для одержання високої врожайності зерна зі збільшеним вмістом білка азот повинен переважати над фосфором у співвідношенні: 1,5-2,0:1,0; $1,25-1,0$. Це сприяє кращому використанню даних елементів в обміні речовин; у рослинах посилено відбуваються процеси синтезу, поліпшується їхній ріст, що в кінцевому результаті сприяє більшому нагромадженню білка та клейковини в зерні [1].

Мета досліджень та методика їхнього проведення. Мета дослідження - вивчення впливу мінерального живлення на елементи продуктивності та показники якості зерна пшениці озимої (вивчалися протягом 2010-2011рр.). Предметом досліджень $є$ сорт Вдала. Дослідження проводили в умовах Лівобережного Лісостепу на базі дослідного поля Полтавського інституту ім. М. І. Вавилова. Повторність - триразова, попередник горох, норма висіву $-5,0$ млн схожих насінин на 1 га, глибина загортання насіння - 4-6 сантиметрів. Варіанти досліду - без захисту, повний захист (гербіциди, інсектициди, фунгіциди) та повний захист + Басфоліар 36 Екстра. Варіанти удобрення - без добрив; $\mathrm{N}_{50} \mathrm{P}_{50} \mathrm{~K}_{50} ; \mathrm{N}_{115} \mathrm{P}_{96} \mathrm{~K}_{51}$; $\mathrm{N}_{85} \mathrm{P}_{96} \mathrm{~K}_{51}+\mathrm{N}_{30} ; \mathrm{N}_{58} \mathrm{P}_{45} \mathrm{~K}_{25} ; \mathrm{N}_{10}$ на 1 т соломи.

* Науковий керівник - доктор сільськогосподарських наук, професор Г. П. Жемела 
Метод проведення досліджень - польовий, доповнений лабораторними аналізами. Визначення показників структури врожайності проводили в пробних снопах, відібраних із двох погонних метрів у двох несуміжних повтореннях. Урожайність визначали методом суцільного зважування. Показники якості зерна пшениці озимої визначали згідно з Державними стандартами та прийнятими методиками в лабораторії якості зерна ПДАА.

Результати досліджень. За результатами проведених досліджень були встановлені показники елементів продуктивності пшениці озимої (табл. 1). Найбільша кількість продуктивних стебел сформована рослинами за умов повного захисту рослин + Басфоліар 36 Екстра, який використовуємо для позакореневого підживлення пшениці. На фоні внесення мінеральних добрив із нормою $\mathrm{N}_{85} \mathrm{P}_{96} \mathrm{~K}_{51}+\mathrm{N}_{30}$ кількість продуктивних стебел нараховує 626 шт./м². Варіант досліду без захисту на всіх фонах удобрення показав найгірші показники (438 шт./M²).

Важливим елементом структури врожайності $\epsilon$ кількість зерен у колосі. Нашими дослідженнями встановлено, що повний захист посівів і 3 підживленням Басфоліар 36 Екстра сприяє збільшенню кількості зерен у колосі та його масі
(36,6 шт. із масою 1,4 г та 37,7 шт. - 1,55 г).

Маса зерна з колоса залежить від передпосівної обробки. Як свідчать дані досліджень, маса зерна із колоса у варіанті (повний захист) без добрив була 1,16 г, на фоні $\mathrm{N}_{85} \mathrm{P}_{96} \mathrm{~K}_{51}+\mathrm{N}_{30}-1,4$ г. У варіанті повний захист + Басфоліар36 Екстра - без добрив $-1,28$ г, на фоні $\mathrm{N}_{85} \mathrm{P}_{96} \mathrm{~K}_{51}+\mathrm{N}_{30}-1,55$ г.

Одним із показників, що широко використовується в практиці характеристики зерна, $є$ його крупність, яка виражається масою 1000 зерен. У наших дослідженнях максимальна маса 1000 зерен була за норми внесення добрив $\mathrm{N}_{85} \mathrm{P}_{96} \mathrm{~K}_{51}+$ $\mathrm{N}_{30}$ і становила 41,0 г. Збільшення дози азотних добрив $\left(\mathrm{N}_{115}\right)$ зменшує масу 1000 зерен (табл. 1).

На рівень урожайності суттєвий вплив має фон удобрення. Найбільша врожайність зерна пшениці озимої спостерігалася за внесення $\mathrm{N}_{85} \mathrm{P}_{96} \mathrm{~K}_{51}+\mathrm{N}_{30}(6,87$ т/га).

У зерні, що використовується на харчові цілі, важливе значення мають клейковина та білок, які в пшениці зумовлюють хлібопекарські властивості борошна.

Збільшений вміст клейковини не лише поліпшує харчову цінність хліба, а $є$ основною умовою добрих хлібопекарських якостей борошна $\mathrm{i}$ значною мірою зумовлює об'ємний вихід хліба.

\section{1. Елементи структури врожайності пшениці озимої залежно від норм внесення мінеральних добрив}

\begin{tabular}{|c|c|c|c|c|c|c|c|c|c|c|c|}
\hline \multirow[t]{2}{*}{$\begin{array}{c}\text { Варіанти } \\
\text { досліду }\end{array}$} & \multirow[t]{2}{*}{$\begin{array}{c}\text { Варіанти } \\
\text { удобрення }\end{array}$} & \multirow{2}{*}{\multicolumn{2}{|c|}{\begin{tabular}{|c|}
\multicolumn{2}{|c}{ Кількість } \\
продуктивних \\
стебел, шт./м² \\
2010 р. 2011 р
\end{tabular}}} & \multicolumn{2}{|c|}{$\begin{array}{c}\text { Кількість зе- } \\
\text { рен у колосі, } \\
\text { шт. }\end{array}$} & \multicolumn{2}{|c|}{$\begin{array}{l}\text { Маса зерна } \\
\text { в колосі, г }\end{array}$} & \multicolumn{2}{|c|}{$\begin{array}{c}\text { Мaca } 1000 \\
\text { зерен, Г }\end{array}$} & \multicolumn{2}{|c|}{$\begin{array}{c}\text { Урожайність, } \\
\text { т/га }\end{array}$} \\
\hline & & & & 2010 p. & $2011 \mathrm{p}$. & $2010 \mathrm{p}$. & $2011 \mathrm{p}$. & $2010 \mathrm{p}$ & $2011 \mathrm{p}$. & $2010 \mathrm{p}$ & $2011 p$ \\
\hline \multirow{6}{*}{$\begin{array}{c}\text { Без } \\
\text { захисту }\end{array}$} & Без/добр. & 400 & 438 & 26 & 27 & 1,01 & 1,02 & 36,4 & 37,5 & 3,9 & 4,25 \\
\hline & $\mathrm{N}_{50} \mathrm{P}_{50} \mathrm{~K}_{50}$ & 480 & 538 & 27 & 32 & 1,1 & 1,2 & 37,0 & 38,0 & 4,8 & 5,48 \\
\hline & $\mathrm{N}_{115} \mathrm{P}_{96} \mathrm{~K}_{51}$ & 500 & 563 & 27 & 32 & 1,2 & 1,19 & 37,1 & 37,6 & 5,0 & 6,08 \\
\hline & $\mathrm{N}_{85} \mathrm{P}_{96} \mathrm{~K}_{51}+\mathrm{N}_{30}$ & 500 & 574 & 30 & 32 & 1,23 & 1,24 & & 38,1 & & 17 \\
\hline & $\mathrm{N}_{58} \mathrm{P}_{45} \mathrm{~K}_{25}$ & 450 & 486 & 29 & 31 & 1,18 & 1,12 & 37,1 & 36,5 & 4,9 & 5,48 \\
\hline & $\mathrm{N}_{10}$ на & 440 & 468 & 26 & 2 & & & & 7,8 & & 5,4 \\
\hline \multirow{6}{*}{$\begin{array}{c}\text { Повний } \\
\text { захист }\end{array}$} & & 405 & 46 & 28 & & & & & & & \\
\hline & $\mathrm{N}_{50} \mathrm{P}_{50} \mathrm{~K}_{50}$ & 480 & 542 & 29 & 33 & 1,2 & 1,34 & 37, & 39,5 & 4,9 & 6,08 \\
\hline & $\mathrm{N}_{115} \mathrm{P}_{96} \mathrm{~K}_{51}$ & 485 & 584 & 30 & 33 & 1,24 & 1,31 & & 39,7 & 5,01 & 6,56 \\
\hline & $\mathrm{N}_{85} \mathrm{P}_{96} \mathrm{~K}_{51}+\mathrm{N}_{30}$ & 540 & 606 & 31 & 36 & 1,3 & 1,4 & & 40,1 & 5,7 & 6,73 \\
\hline & $\mathrm{N}_{58} \mathrm{P}_{45} \mathrm{~K}_{25}$ & 493 & 548 & 30 & 33 & 1,3 & 1,26 & 38 & 37,9 & 5,6 & 6,04 \\
\hline & & 480 & 496 & 29 & 31 & 1,26 & 1,26 & & 38,5 & 5,43 & 6,07 \\
\hline \multirow{6}{*}{$\begin{array}{c}\text { Повний } \\
\text { захист+ } \\
\text { Басфо- } \\
\text { ліар36 } \\
\text { Екстра }\end{array}$} & & 415 & 49 & 29 & & & 1,28 & & 9,6 & & 4,94 \\
\hline & $\mathrm{N}$ & 491 & 58 & 3 & 3 & 1,2 & 1,36 & & 0,6 & 4,98 & 6,28 \\
\hline & $\mathrm{N}_{115} \mathrm{P}_{96} \mathrm{~K}_{51}$ & 501 & 596 & 31 & 34 & 1,3 & 1,36 & 39 & 39,9 & 5,1 & 6,65 \\
\hline & $\mathrm{N}_{85} \mathrm{P}_{96} \mathrm{~K}_{51}+\mathrm{N}_{30}$ & 583 & 626 & 33 & 37 & 1,36 & 1,55 & 40,8 & 41,0 & 5,45 & 6,87 \\
\hline & $\mathrm{N}_{58} \mathrm{P}_{45} \mathrm{~K}_{25}$ & 523 & 560 & 30 & 34 & 1,29 & 1,32 & 38,1 & 38,2 & 5,4 & 6,27 \\
\hline & $\mathrm{N}_{10}$ на 1т п.пр. & 493 & 518 & 29 & 32 & 1,27 & 1,28 & 38,0 & 39,0 & 5,1 & 6,19 \\
\hline
\end{tabular}




\section{2. Вплив мінерального жсилення на якість зерна пшениці озимої}

\begin{tabular}{|c|c|c|c|c|c|c|c|}
\hline \multirow{2}{*}{$\begin{array}{l}\text { Варіанти } \\
\text { досліду }\end{array}$} & \multirow{2}{*}{$\begin{array}{l}\text { Варіанти } \\
\text { удобрення }\end{array}$} & \multicolumn{2}{|c|}{ Вміст клейковини, \% } & \multicolumn{2}{|c|}{$\begin{array}{c}\text { Якість клейковини, од. } \\
\text { ВДК-1 } \\
\end{array}$} & \multicolumn{2}{|c|}{ Вміст білка, \% } \\
\hline & & $2010 \mathrm{p}$. & $2011 \mathrm{p}$. & $2010 \mathrm{p}$. & 2011 p. & $2010 \mathrm{p}$. & $2011 \mathrm{p}$. \\
\hline \multirow{6}{*}{$\begin{array}{c}\text { Без } \\
\text { захисту }\end{array}$} & Без добрив & 21,0 & 20,8 & 100 & 100 & 8,2 & 8,0 \\
\hline & $\mathrm{N}_{50} \mathrm{P}_{50} \mathrm{~K}_{50}$ & 21,8 & 21,0 & 98 & 98 & 9,8 & 9,6 \\
\hline & $\mathrm{N}_{115} \mathrm{P}_{96} \mathrm{~K}_{51}$ & 22,8 & 22,1 & 106 & 106 & 10,8 & 10,5 \\
\hline & $\mathrm{N}_{85} \mathrm{P}_{96} \mathrm{~K}_{51}+\mathrm{N}_{30}$ & 24,0 & 23,4 & 100 & 100 & 11,9 & 11,4 \\
\hline & $\mathrm{N}_{58} \mathrm{P}_{45} \mathrm{~K}_{25}$ & 21,0 & 20,6 & 101 & 101 & 11,5 & 11,1 \\
\hline & $\mathrm{N}_{10}$ на 1 т п.пр. & 20,9 & 19,8 & 96 & 96 & 10,5 & 10,0 \\
\hline \multirow{6}{*}{$\begin{array}{c}\text { Повний } \\
\text { захист }\end{array}$} & Без добрив & 21,0 & 20,1 & 81 & 81 & 8,4 & 8,0 \\
\hline & $\mathrm{N}_{50} \mathrm{P}_{50} \mathrm{~K}_{50}$ & 21,8 & 20,4 & 83 & 83 & 8,5 & 8,2 \\
\hline & $\mathrm{N}_{115} \mathrm{P}_{96} \mathrm{~K}_{51}$ & 23,0 & 22,9 & 88 & 88 & 11,6 & 11,1 \\
\hline & $\mathrm{N}_{85} \mathrm{P}_{96} \mathrm{~K} 51+\mathrm{N}_{30}$ & 25,0 & 24,9 & 95 & 95 & 12,1 & 11,6 \\
\hline & $\mathrm{N}_{58} \mathrm{P}_{45} \mathrm{~K}_{25}$ & 22,8 & 22,0 & 90 & 90 & 11,6 & 10,7 \\
\hline & $\mathrm{N}_{10}$ на 1 т п.пр. & 21,9 & 19,1 & 84 & 84 & 10,0 & 8,7 \\
\hline \multirow{6}{*}{$\begin{array}{c}\text { Повний } \\
\text { захист+ } \\
\text { Басфо- } \\
\text { ліар } 36 \\
\text { Екстра }\end{array}$} & Без добрив & 21,8 & 21,0 & 83 & 83 & 9,3 & 9,0 \\
\hline & $\mathrm{N}_{50} \mathrm{P}_{50} \mathrm{~K}_{50}$ & 22,9 & 22,1 & 90 & 90 & 10,2 & 9,6 \\
\hline & $\mathrm{N}_{115} \mathrm{P}_{96} \mathrm{~K}_{51}$ & 23,0 & 22,1 & 81 & 81 & 11,6 & 11,2 \\
\hline & $\mathrm{N}_{85} \mathrm{P}_{96} \mathrm{~K}_{51}+\mathrm{N}_{30}$ & 25,9 & 25,3 & 80 & 80 & 12,8 & 12,2 \\
\hline & $\mathrm{N}_{58} \mathrm{P}_{45} \mathrm{~K}_{25}$ & 24,1 & 23,7 & 84 & 84 & 11,1 & 10,8 \\
\hline & $\mathrm{N}_{10}$ на 1 т п.пр. & 22,0 & 20,3 & 80 & 80 & 10,4 & 9,8 \\
\hline
\end{tabular}

Вміст білка і клейковини в зерні суттєво змінюється від фону удобрення. Зі збільшенням доз мінеральних добрив збільшується вміст білка i клейковини в зерні пшениці. Так, на фоні без захисту вміст білка в зерні в середньому за 2010-2011 рр. збільшився від 8,0 \% до 11,4 \%; на фоні повного захисту - 8,0-11,6 \%; фон повного захисту + Басфоліар 36 Екстра - 9,0-12,2\% (табл. 2).

Вміст клейковини в зерні змінювався аналогічно вмісту білка, проте вона має суттєве значення в макаронному виробництві, виконуючи дві основні функції: $є$ пластифікатором, тобто виконує роль своєрідного мастила, а також виступає зв'язуючою речовиною, що з'єднує крохмальні зерна в суцільну масу. Перша властивість клейковини сприяє формуванню тіста, друга - зберігає надану тісту форму.

Відповідно до наших досліджень, лише вне-

\section{БІБЛІОГРАФІЯ}

1. Дацько Л. В. Розрахунок балансу поживних речовин у землеробстві України // Посібник українського хлібороба.- К. : Веста, 2008.C. 65-68.

2. Дегодюк С. Г., Мамонтов В. Т., Гамалей В. I. Екологічні основи використання добрив.- К. : Урожай, 1988. - 232 с.

3. Жемела Г. П. Добрива, урожай і якість зер- сення азотних добрив у кількості 58, 85 і 115 кг діючої речовини на гектар у поєднанні 3 фосфорно-калійними добривами забезпечило найвищий вміст клейковини та білка в зерні (відповідно, 24,1 г, 25,9 г, 23,0 г).

\section{Висновки:}

1. Формування високопродуктивних посівів пшениці озимої значною мірою залежить від передпосівної обробки насіння та рівня підживлення (Басфоліар 36 Екстра).

2. Проведенні нами дослідження дали змогу встановити певні закономірності впливу мінерального живлення на формування зерна пшениці озимої.

3. За результатами наукових досліджень встановлено, що найраціональніша норма внесення мінеральних добрив $-\mathrm{N}_{85} \mathrm{P}_{96} \mathrm{~K}_{51}+\mathrm{N}_{30}$, яка сприяє ефективному поліпшенню показників структури врожайності.

на. - К. : Урожай, 1991. - 136 с.

4. Лихочвор B. В. Структура врожаю озимої пшениці // Монографія / Львів : Українські технології, 1999. - 200 с.

5. Морфология, биология, хозяйственная ценность пшеницы / В. В. Шелепов, В. М. Маласай, А. Ф. Пензев. - Мироновка, 2004. - 524 с. 